\title{
Perancangan Aplikasi Try Out Ujian Nasional Tingkat Sekolah Menengah Atas
}

\author{
Monica G. Tangui, Hans Wowor, Stanley Karouw \\ Teknik Informatika Universitas Sam Ratulangi Manado, Indonesia. \\ monicagabrielatangui@gmail.com, hanswowor@unsrat.ac.id, stanley.karouw@unsrat.ac.id
}

\begin{abstract}
Abstrak - Persiapan dalam menghadapi ujian nasional berbasis computer based test perlu dilakukan oleh sekolah agar siswa dapat membiasakan diri dalam menghadapi ujian berbasis komputer. Salah satu cara yang dapat dilakukan sekolah adalah dengan melaksanakan ujian try out. Namun ujian try out masih dilakukan secara manual. Oleh karena itu, tujuan dari penelitian ini adalah mengembangkan aplikasi try out ujian nasional berbasis web agar dapat membantu melatih siswa dalam menghadapi ujian nasional berbasis komputer. Aplikasi Try Out Ujian Nasional berbasis web ini dirancang dengan menggunakan metode prototype.
\end{abstract}

Penelitian ini menghasilkan aplikasi try out ujian nasional yang dapat digunakan siswa dalam mengikuti ujian try out berbasis komputer dan sebagai media evaluasi untuk pemerintah.

Kata kunci : Aplikasi, CBT, Prototype, try out, Ujian Nasional

\section{PENDAHULUAN}

Berdasarkan Undang-undang tentang Sistem Pendidikan Nasional nomor 20 tahun 2003, Ujian Nasional adalah sistem evaluasi standar pendidikan dasar dan menengah secara nasional dan persamaan mutu tingkat pendidikan antar daerah yang dilakukan oleh Pusat Penilaian Pendidikan, Depdiknas di Indonesia.

Setiap tahunnya Ujian Nasional dilakukan evaluasi, dan pada tahun 2015 Ujian Nasional telah dilakukan secara online di beberapa sekolah. Pada tahun 2016 pelaksanaan UN secara online telah dilaksanakan pada 479 Sekolah di Indonesia dan 5 Sekolah di Kota Manado[3].

Sebelum dilaksanakannya Ujian Nasional seringkali setiap sekolah melaksanakan ujian try out untuk melihat kesiapan siswa, namun pelaksanaan Ujian try out masih dilakukan secara manual dan untuk mengetahui hasilnya harus menunggu beberapa hari sampai beberapa minggu.

Ujian Nasional online juga memiliki beberapa masalah seperti, kesiapan dan permasalahan kejelasan ujian nasional kepada siswa (masih kurangnya sosialisasi dan pelatihan lebih lanjut kepada guru, pengawas, dan siswa) sehingga membuat guru dan siswa kebingungan, ketidaksiapan siswa dalam menghadapi ujian nasional dan masih banyak siswa SMA yang tidak dapat mengoperasikan komputer dan menghadapi soal-soal berbasis CBT.

Ujian Nasional merupakan sistem evaluasi dimana pemerintah akan menilai indeks integritas dan rata-rata Ujian Nasional di setiap kabupaten/kota dan sekolah. Karena hal tersebut, maka setiap pemerintah daerah mengharapkan kelulusan $100 \%$ dari setiap siswa disekolah-sekolah yang ada. Setiap sekolah yang ada di tiap daerah pun berharap dan dituntut agar siswanya lulus ujian nasional $100 \%$ sehingga banyak sekolah yang mengambil langkah yang salah yaitu kecurangan seperti, membagikan kunci jawaban kepada siswa, memanipulasi nilai sekolah untuk memenuhi tuntutan tersebut. Dalam mencapai Indeks Intergritas yang baik diperlukan perhatian pemerintah seperti evaluasi dan monitoring namun hal ini menjadi sulit karena kurangnya alat bantu dalam melakukan evaluasi dan monitoring disetiap sekolah yang ada.

Dengan demikian perlu dibangun aplikasi untuk melakukan ujian try out, sambil mempertimbangkan batasan-batasan di atas. Dari hal tersebut maka penulis mengangkat judul "Perancangan Aplikasi Try Out Ujian Nasional Tingkat Sekolah Menengah Atas (SMA)”.

\section{LANDASAN TEORI}

\section{A. Ujian Nasional}

Menurut Peraturan Menteri Pendidikan Nasional No 77 Tahun 2008 tentang Ujian Nasional Sekolah Menengah Atas/Madrasah Aliyah, Ujian Nasional yang selanjutnya disebut UN adalah kegiatan pengukuran dan penilaian kompetensi peserta didik secara nasional pada jenjang pendidikan menengah. Ujian Nasional bertujuan menilai pencapaian kompetensi lulusan secara nasional pada mata pelajaran tertentu dalam kelompok mata pelajaran ilmu pengetahuan dan teknologi.

Hasil UN digunakan sebagai salah satu pertimbangan untuk : a. pemetaan mutu satuan dan/atau program pendidikan; b. dasar seleksi masuk jenjang pendidikan berikutnya; c. penentuan kelulusan peserta didik dari program dan/atau satuan pendidikan; d. pembinaan dan pemberian bantuan kepada satuan pendidikan dalam upaya peningkatan mutu pendidikan. UN diselenggarakan oleh BSNP yang pelaksanaannya bekerja sama dengan instansi terkait dilingkungan pemerintah, pemerintah provinsi, perguruan tinggi, pemerintah kabupaten/kota, dan satuan pendidikan.

Menurut Peraturan Badan Standart Nasional pendidikan nomor 0031 tahun 2015, Ujian nasional terdiri dari dua yaitu

1. Ujian nasional berbasis Kertas (Paper based Test, PBT) yang selanjutnya disebut UN-PBT adalah sistem ujian yag digunakan dalam UN dengan menggunakan naskah soal dan Lembar Jawaban Ujian Nasional (LJUN) berbasis kertas.

2. Ujian Nasional Berbasis Komputer (Computer based Test, CBT) yang selanjutnya disebut UNCBT adalah sistem ujian yang digunakan dalam UN dengan menggunkan sistem komputer. 


\section{B. Aplikasi Web}

Layanan Web atau dikenal dengan WWW (world wide web) yaitu sebuah sistem dimana informasi dalam bentuk teks, suara, gambar, video, animasi dapat direpresentasikan dalam bentuk hypertext dan dapat diaskses oleh perangkat lunak yang disebut browser.

Aplikasi berbasis web membutuhkan dua teknologi yaitu teknologi untuk server dan teknologi untuk client. Teknologi server adalah web server dimana server ini menjalankan layanan untuk memformat data menggunakan bahasa pemrograman seperti PHP, Perl, dan Java. Hasil yang sudah diformat oleh web server dikirim ke client, dimana client membutuhkan web browser untuk membaca dan menampilkan data dari web server[5].

\section{C. $M y S Q L$}

MySQL adalah Relational Database Management Sistem ( RDBMS ) yang didistribusikan secara gratis di bawah lisensi General Public license (GPL). Dimana setiap orang bebas untuk menggunakan, namun tidak boleh dijadikan produk turunan yang bersifat closed source atau komersil.

MySQL sebenarnya merupakan turunan salah satu konsep uatama dalam database sejak lama yaitu SQL (Structure Query Language). SQL adalah bahasa standar yang digunakan untuk mengakses database server. Bahasa ini pada awalnya dikembangkan oleh IBM, namun telah di adopsi dan digunakan sebagai standar industri. Dengan menggunakan SQL, proses akses database menjadi lebih user-friendly dibandingkan dengan menggunakan perintah-perintah pemograman dBASE atau Clipper yang masih menggunakan perintah-perintah pemograman[4].

\section{PHP}

PHP adalah bahasa pemograman script yang paling banyak dipakai saat ini. PHP adalah bahasa pemograman web atau scripting language yang didesain untuk web [10].

Awalnya PHP merupakan kependekan dari Personal Home Page. PHP dibuat pertama kali oleh Rasmus Leodorf pada 1994, yang pada awalnya dibuat untuk menghitung jumlah pengunjung pada homepage-nya. Pada waktu itu PHP masih bernama FI(Form Interpreted), yang wujudnya berupa sekumpulan script yang digunakan untuk mengelolah data form dari web. Di awal januari 2001, PHP telah dipakai lebih dari 5 juta domain diseluruh dunia, dan akan terus bertambah karena kemudahan aplikasi PHP ini dibandingkan dengan bahasa Server side yang lain.

PHP banyak dipakai untuk membuat situs web yang dinamis, walaupun tidak menutup kemungkinan digunakan untuk pemakaian lain. PHP biasanya berjalan pada sistem operasi linux (PHP juga bisa dijalankan dengan hosting windows)[10].

\section{E. Framework PHP Codeigniter}

PHP Framework adalah sebuah lingkungan pengembangan aplikasi berbasis php yang berisi sejumlah class yang telah dibuat agar digunakan kembali untuk membuat aplikasi. Berbagai jenis class ini tergantung tujuan dari PHP framework tersebut, dan php framework yang satu dengan framework yang lain kemungkinan berbeda. Sebagian besar php framework yang tersedia saat ini berbasis MVC(Model View Controller). Ini adalah model php framework yang modern[10].
Codeigniter adalah aplikasi open source yang berupa Framework dengan model MVC(Model View Controller) untuk membangun website dinamis. Dengan menggunakan PHP Codeigniter akan memudahkan developer untuk membuat aplikasi web dengan cepat dan mudah dibandingkan dengan membuatnya dari awal.

Menurut Gugun Septian (2011) MVC adalah sebuah pendekatan perangkat lunak yang memisahkan aplikasi logika dari presentasi. Ini meminimalkan script dari halaman-halaman web sejak script presentasi (HTML, CSS, Javascript, dsb) dipisahkan dari PHP scripting. Istilah umum yang familiar adalah menghindari terjadinya spagetti code.

1. Model

Merepresentasikan strutur data yang dibangun. Umumnya kelas model berisi fungsi-fungsi yang membantu developer untuk mengelola, memasukan, dan mengupdate informasi dalam database.

2. View

View adalah informasi yang disajikan untuk user, berupa tampilan atau user interface. View umumnya adalah tampilan sebuah halaman web itu sendiri, tetapi dalam Codeigniter, view dapat juga menjadi bagian bagian atau penggalan - penggalan halaman seperti header atau footer. View dapat juga sebagai halaman RSS atau tipe - tipe halaman lainnya.

\section{Controller}

Bertugas sebagai penghubung antara Model, View, dan beberapa resource lainnya yang dibutuhkan untuk memproses HTTP request dan untuk meng-generate sebuah halaman web.

\section{F. Prototype}

Menurut Pressman (2012), Pembuatan Prototype (Prototyping). Seringkali pelanggan mendefinisikan sejumlah sasaran perangkat lunak secara umum, tetapi tidak bisa mengidentifikasi spesifikasi kebutuhan yang rinci untuk fungsi-fungsi dan fitur-fitur yang nantinya akan dimiliki perangkat lunak yang akan dikembangkan. Dalam kasus yang lain, pengembang perangkat lunak mungkin merasa tidak pasti tentang efisiensi suatu algoritma yang akan digunakan dalam pengembangan perangkat lunak, atau juga merasa tidak pasti akan kemampuan perangkat lunak untuk beradaptasi dengan sistem operasi yang akan digunakan, akan merasa tidak pasti akan bentuk interaksi manusia-komputer yang akan digunakan. Dalam kasus-kasus seperti ini dan dalam banyak situasi yang lain, paradigm pembuatan prototype(prototyping) mungkin menawarkan pendekatan yang paling baik.

Meskipun pembuatan prototype dapat digunakan sebagai model proses yang berdiri sendiri, pembuatan prototype lebih umum digunakan sebagai teknik yang dapat diimplementasikan di dalam konteks setiap model proses perangkat lunak yang telah dan akan kita bahas dalam bab ini. Dalam hal ini, tidak terlalu peduli dengan di mana ia diterapkan, paradigma pembuatan prototype seringkali membantu tim pengembang perangkat lunak dan para stakeholder untuk memahami lebih baik apa yang akan dikembangkan saat spesifikasi kebutuhan belum jelas[6]. 


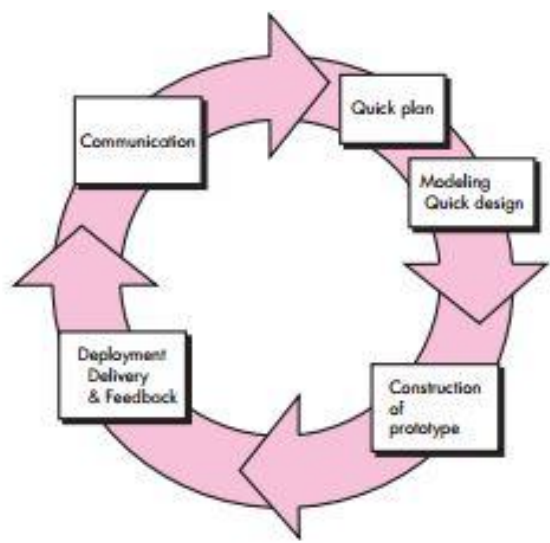

Gambar 1. Metode Prototype

\section{METODOLOGI PENELITIAN}

\section{A. Identifikasi Masalah}

Identifikasi masalah dari hasil observasi di SMA Negeri 7 Manado adalah sebagai berikut

1. Proses ujian Try Out Ujian Nasional masih manual dan membutuhkan waktu yang cukup lama untuk mengetahui hasil ujian.

2. Proses Evaluasi pemerintah terhadap setiap sekolah masih memakan waktu yang lama. Pemerintah harus mendatangi setiap sekolah satu per satu untuk melakukan evaluasi.

\section{B. Pengumpulan Data}

Metode pengumpulan data yang digunakan peneliti pada penelitian ini terdiri dari :

1. Studi Literatur

Mencari dan mengumpulkan referensi dari berbagai sumber dan dari buku-buku yang berhubungan dengan masalah pada penelitian.

2. Observasi

Observasi dilakukan dengan turun langsung ke SMA Negeri 7 Manado untuk mengumpulkan data berupa bagaimana dinas melakukan evaluasi terhadap sekolah

3. Kuisioner

Kuisioner disebarkan kepada 30 siswa - siswi yang baru lulus ujian nasional tahun 2015 dan kepada guru-guru dari sekolah SMK Negeri 2 Manado dan SMA Negeri 7 Manado.

\section{Metode Pengembangan Aplikasi}

Metode Pengembangan Aplikasi yang digunakan untuk membangun aplikasi try out ujian nasional ini yaitu dengan menggunakan metode prototype yang terdiri dari 5 tahapan pengembangan perangkat lunak yaitu Tahap Komunikasi, Tahap Perencanaan secara cepat, Tahap Pemodelan Perancangan secara cepat, Tahap Pembentukan Prototype, Tahap Penyerahan Sistem.

\section{Tahap Komunikasi}

Pada tahap ini dilakukan pengumpulan data dengan berkomunikasi dengan pengguna untuk mengidentifikasi spesifikasi kebutuhan.

\section{Tahap Perencanaan secara cepat}

Pada tahap ini dilakukan perencanaan tentang tools apa saja yang akan digunakan dalam membangun aplikasi ini sesuai dengan hasil pada tahap sebelumnya.

3. Tahap Pemodelan Perancangan Secara Cepat Dalam tahap penulis akan menganalisa kebutuhankebutuhan perangkat lunak yang akan dibutuhkan nantinya, mendesain cara kerja dari sistem yang akan dibuat, interface, dan fitur-fitur yang diperlukan.

\section{Tahap Pembentukan Prototype}

Pada tahap ini dilakukan penulisan kode kedalam program sesuai dengan tahap perancangan yang telah dibuat dan tools yang telah ditentukan sebelumnya dan dilakukan pengujian sistem.

5. Tahap Penyerahan Sistem/Perangkat lunak

Pada tahap ini aplikasi yang telah melewati tahap pengujian siap untuk diimplementasikan di SMA Negeri 7 Manado.

\section{HASIL DAN PEMBAHASAN}

\section{A. Tahap Komunikasi}

Pada tahap ini, peneliti mengidentifikasi spesifikasi kebutuhan yang dibutuhkan dengan cara observasi dan berkomunikasi langsung dengan pengguna serta membagikan kuisioner untuk memperoleh data-data yang dibutuhkan.

Data diperoleh dari hasil kuisioner yang telah dibagikan kepada siswa-siswi. Data-data Sekolah yang siap mengkuti ujian nasional dapat diketahui dari hasil evaluasi dinas dengan berkunjung ke setiap sekolah yang ada.

Sampai sekarang belum ada aplikasi try out ujian nasional yang dapat membantu siswa-siswi dalam menghadapi ujian nasional berbasis CBT dan sekaligus menjadi alat untuk evaluasi setiap sekolah bagi Dinas Pendidikan. Sampai saat ini proses evaluasi tiap sekolah belum berbasis aplikasi sehingga kurang efisien.

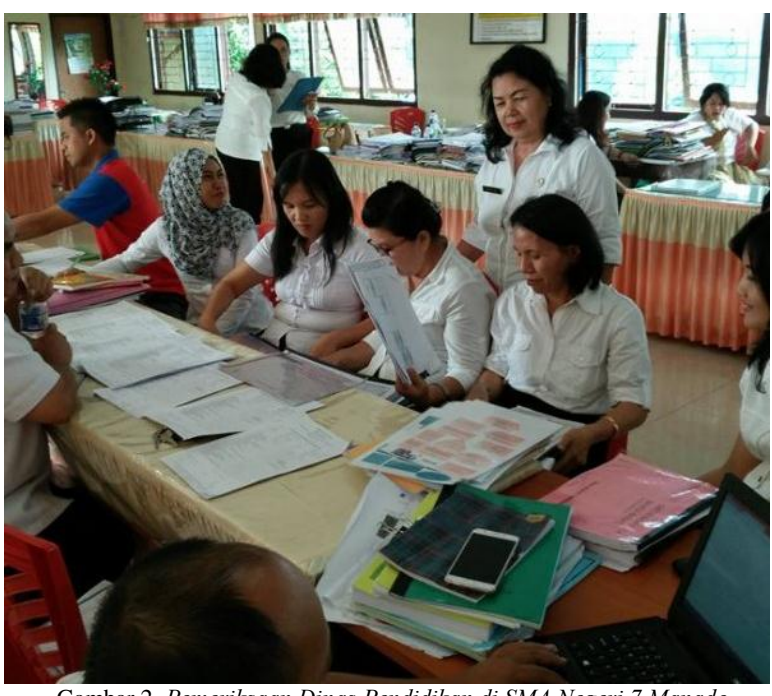

Gambar 2. Pemeriksaan Dinas Pendidikan di SMA Negeri 7 Manado 


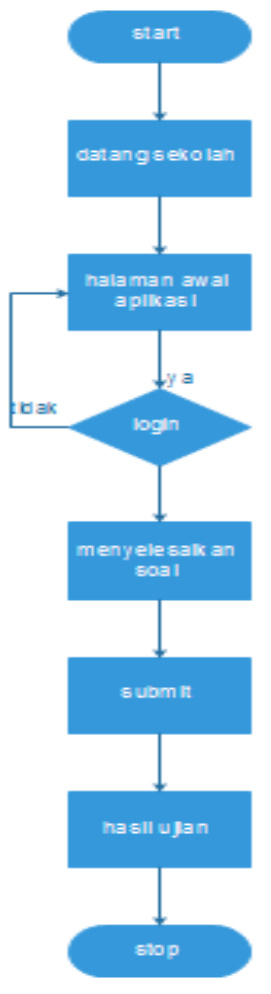

Gambar 3. Proses Bisnis Setelah Menggunakan Aplikasi

Pada gambar 3, menunjukan proses try out ujian nasional setelah menggunakan aplikasi nantinya, dengan dimulai dari siswa datang ke sekolah membuka halaman awal aplikasi, melakukan login jika login berhasil, siswa menyelesaikan soal, kemudian submit jawaban dan langsung dapat melihat hasil ujian.

\section{B. Tahap Perencanaan Secara Cepat}

Pada tahap ini penulis akan mendefinisikan batas waktu dan informasi yang berhubungan dengan aplikasi dalam batas waktu yang singkat dengan membuat jadwal penelitian dan menentukan tools apa saja yang akan digunakan.

Tool yang akan digunakan dalam pembuatan aplikasi ini berupa

1) Notepad++ 6.7.5

2) Sublime text 2.0.2

3) Xampp 3.2.1

4) Google Chrome 49.0.2623.87

5) Microsoft Word 2013

Aplikasi yang akan dirancang menggunakan framework Codeigniter.

\section{Tahap Pemodelan Perancangan Secara Cepat}

Pada tahap ini penulis akan menganalisa kebutuhankebutuhan perangkat lunak yang akan di butuhkan nantinya dan penulis akan mendesain cara kerja dari sistem yang akan di buat, interface, dan fitur-fitur yang diperlukan.

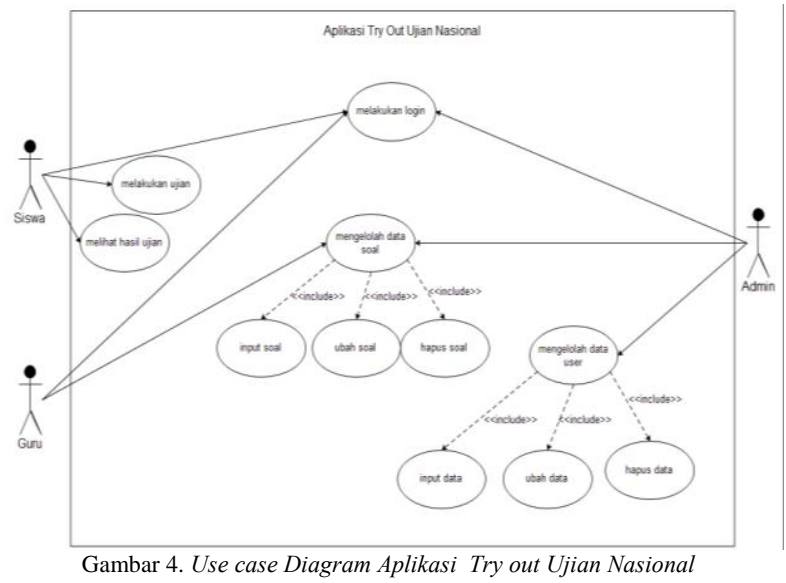

Use case selalu didefinisikan dari sudut pandang actor-aktor yang berinteraksi dengan sistem/perangkat lunak yang sedang dikembangkan. Sebuah actor pada dasarnya merupakan peran (role) yang orang-orang atau sarana-sarana mainkan saat mereka berinteraksi dengan perangkat lunak[6].

Aplikasi Tryout ujian nasional memiliki usecase diagram seperti pada gambar 4.

Class Diagram Aplikasi Try Out Ujian Nasional memberikan gambaran struktur sistem dari segi pendefinisian klas yang akan dibuat untuk membengun sistem.

Aplikasi Try Out Ujian Nasional memiliki Class Diagram seperti pada gambar 5.

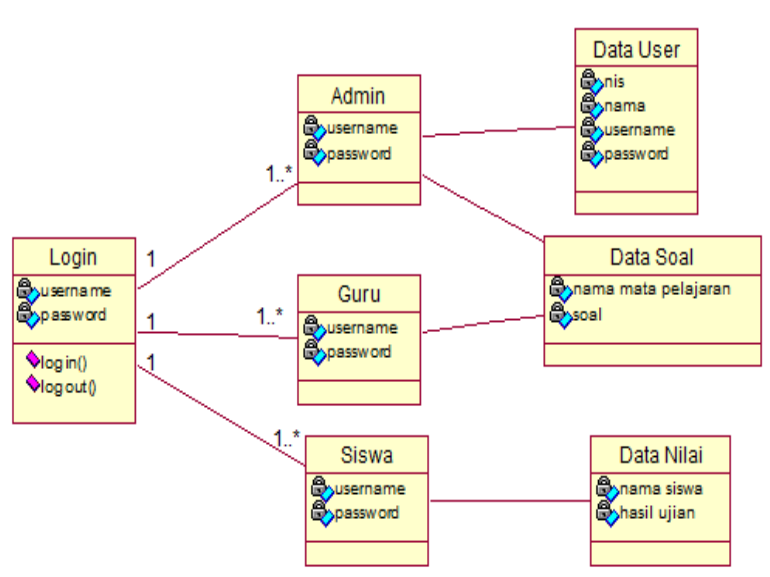

Gambar 5. Class Diagram Aplikasi Try out Ujian Nasional 


\section{Tahap Pembentukan Prototype Implementasi Basis data}

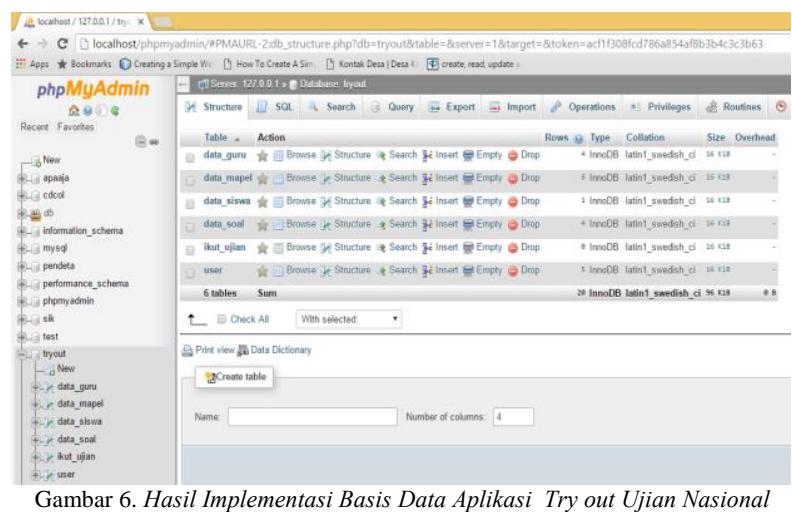

Pada tahap ini penulis akan melakukan penulisan kode kedalam program sesuai dengan tahap perancangan yang telah dibuat dan tools yang telah ditentukan sebelumnya. Kemudian akan dilakukan pengujian sistem untuk mengetahui apakah sistem tersebut masih di temukan kesalahan sehingga harus di perbaiki atau tidak.

Implementasi basis data adalah membuat basis data dengan membuat tabel-tabel yang sudah dideslripsikan di tahapan pemodelan ke dalam Sistem Manajemen Basis Data. Pada penelitian ini menggunakan MySQL untuk memudahkan pembuatan basis data.

\section{Implementasi Sistem}

Implementasi Sistem adalah menerjemahkan fungsi yang telah didefinisikan ke dalam bentuk kode program. Sistem try out ujian nasional tingkat sekolah menengah atas menggunakan bahasa pemograman berbasis web yaitu framework PHP Codeigniter.

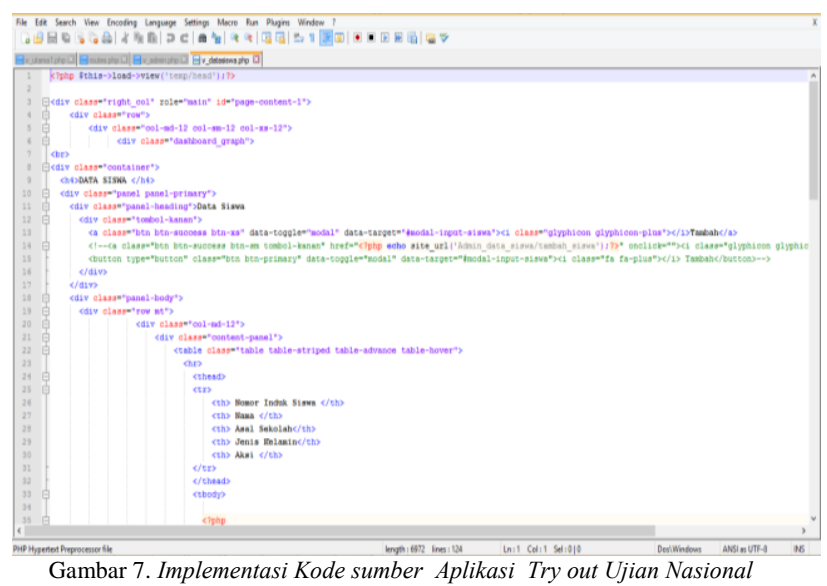

Implementasi User Interface

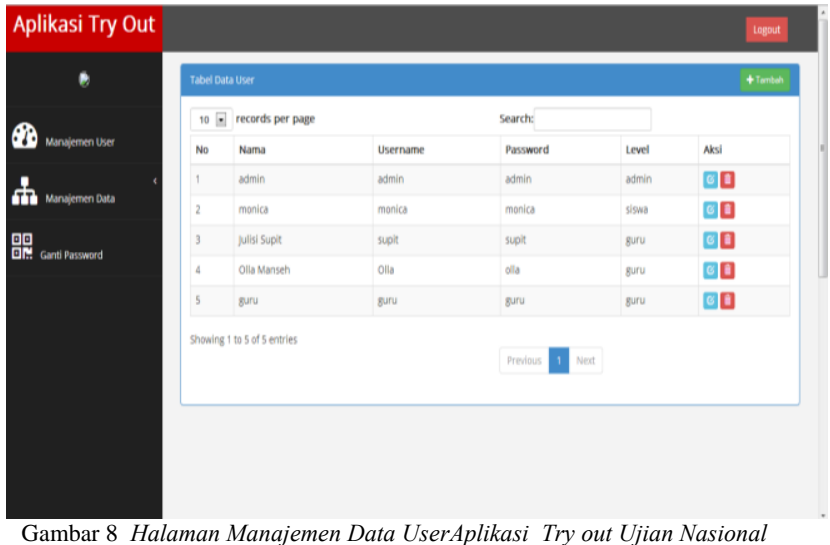

Halaman awal sistem admin menampilkan fitur-fitur sistem yang bisa diakses user yang memiliki status admin mulai dari melihat, mengubah, dan menghapus data. Data-data tersebut antara lain data user, data siswa, data guru, data soal, dan data nilai.

Halaman Manajemen Data user hanya dapat diakses oleh user dengan status admin. Gambar 9 merupakan gambar salah satu halaman manajemen data yang hanya dapat diakses oleh user yang memiliki status admin

Tampilan Halaman Utama Siswa. Aktor Siswa hanya dapat melakukan Ujian dan melihat hasil dari ujian yang telah dilakukan serta dengan soal dan jawaban yang benar dan jawaban yang salah.

Gambar 10 merupakan gambar halaman untuk ujian bahasa Indonesia untuk user dengan status sebagai siswa.

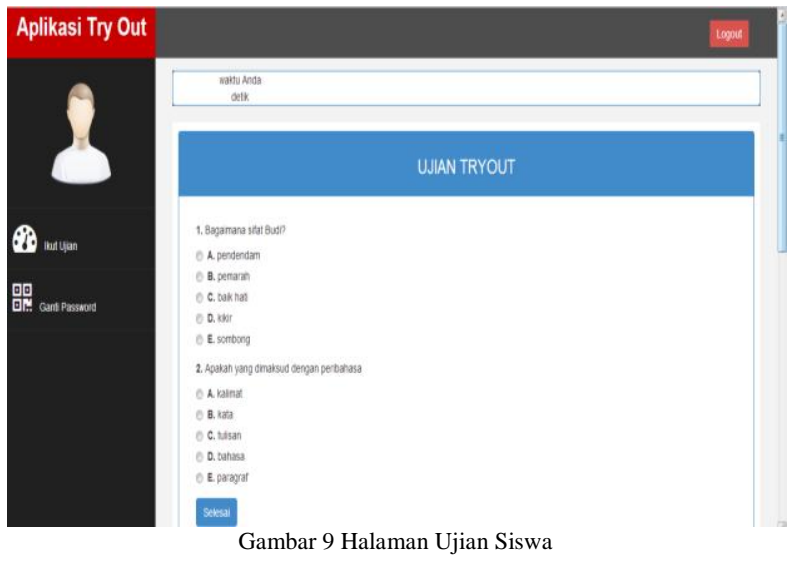




\section{A. Kesimpulan}

\section{PENUTUP}

Sebelum dilaksanakannya Ujian Nasional seringkali setiap sekolah melaksanakan ujian try out untuk melihat kesiapan siswa, namun pelaksanaan Ujian try out masih dilakukan secara manual dan untuk mengetahui hasilnya harus menunggu beberapa hari sampai beberapa minggu.

Hasil Penelitian ini adalah telah dibuat aplikasi try out ujian nasional berbasis web yang digunakan untuk membantu siswa-siswi dalam menghadapi ujian nasional tingkat Sekolah Menenangah Atas (SMA) dan membantu sekolah dan pemerintah dalam melakukan evaluasi. Aplikasi try out ujian nasional memiliki fasilitas mengikuti ujian dan melihat hasil ujian setelah selesai ujian yang membantu siswa-siswi mengetahui apakah jawaban mereka benar atau salah. Selain itu aplikasi ini dilengkapi dengan fitur untuk menampilkan data siswa, guru dan hasil ujian sehingga memudahkan sekolah dan dinas untuk melakukan evaluasi dan pemantauan dalam kegiatan ujian nasional.

\section{B. Saran}

Berdasarkan hasil penelitian dan kesimpulan dari aplikasi try out ujian nasional, maka terdapat beberapa saran diantaranya :

1. Aplikasi try out ujian nasional ini dapat menjadi alternative pilihan utuk dijadikan alat bantu dalam melakukan evaluasi dan monitoring terhadap siswa dan sekolah

2. Penelitian terhadap aplikasi ini dapat dikembangkan menjadi aplikasi mobile sehingga aplikasi ini dapat menjadi lebih baik dan lebih bermanfaat lagi.

3. Aplikasi Try out ujian nasional ini dapat diimplementasikan oleh pemerintah sebagai media evaluasi.

\section{DAFTAR PUSTAKA}

[1] Dharwiyanti, S., \& Wahono S, R. (2003). Pengantar Unified Modeling Language (UML). Kuliah Umum Ilmu Komputer

\section{[2] Indriasari, S. (2012). SISTEM INFORMASI BERBASIS WEB UNTUK MEMBANTU KEGIATAN TRACER STUDY PROGRAM DIPLOMA INSTITUT PERTANIAN BOGOR. Program Keahlian Manajemen Informatika.}

[3] Kemendikbud.(2016). Ujian Nasional Berbasis Komputer(UNBK). Kementerian Pendidikan dan Kebudayaan. Website http://unbk.kemdikbud.go.id/sekolah

[4] Nugroho \& Bunafit. (2005). Database Relasional dengan MySQL, Penerbit Andi. Yogyakarta

[5] Purbadian, Y. (2015). Aplikasi Penjualan Web Base dengan PHP untuk Panduan Skripsi. CV. ASFA Solution. Sukabumi
[6] Pressman, S. R. (2012). Rekayasa Perangkat Lunak Pendekatan Praktisi Edisi 7- Buku 1. Penerbit Andi. Yogyakarta

[7] Republik Indonesia. 2003. Undang-undang No. 20 Tahun 2003 tentang Sistem Pendidikan Nasional.

[8] Republik Indonesia. 2008 Peraturan menteri pendidikan Nasional No.77 Tahun 2008 tentang Ujian Nasional Sekolah Menengah Atas/madrasah Aliyah.

[9] Republik Indonesia. 2015 Peraturan Badan Standart Nasional Pendidikan No.0031 Tahun 2015 tentang Ujian Nasional.

[10] Septian, G. (2011). Trik Menguasai Codeigniter. PT Elex Media komputindo. Jakarta

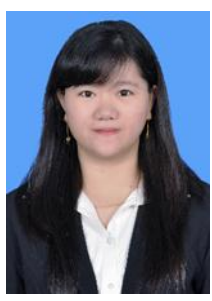

Sekilas tentang penulis dengan nama lengkap Monica G. tangui, pada tanggal 01 Februari 1995 lahir di kota Manado, provinsi Sulawesi Utara. Penulis merupakan anak ke-3 dari 3 bersaudara dengan latar belakang pendidikan Sekolah Dasar Katolik 05 kota Manado, Setelah lulus

melanjutkan ke Sekolah Menengah Pertama Frater Don Bosco Manado. Kemudian melanjutkan ke Sekolah Menengah Atas Negeri 7 Manado dan dinyatakan lulus pada tahun 2012 lalu melanjutkan ke Perguruan Tinggi di Universitas Sam Ratulangi Manado dengan mengambil Jurusan Elektro Program Studi Teknik Informatika. Pada tahun 2015 bulan Juli, penulis membuat Skripsi demi memenuhi syarat memperoleh gelar Sarjana (S1) dengan penelitian berjudul Perancangan Aplikasi Try Out Ujian Nasional Tingkat Sekolah Menengah Atas yang dibimbing oleh dua dosen pembimbing yaitu Ir. Hans F. Wowor, M.Kom, dan Stanley D.S. Karouw ST.,MTI serta pada tanggal 4 Oktober 2016 penulis resmi lulus dari Program Studi Teknik Informatika Jurusan Elektro Fakultas Teknik Universitas Sam Ratulangi Manado dan menyandang gelar Sarjana Komputer. 

